\title{
Stability evaluation of slopes of earth dams with account of soil rheological properties
}

\author{
D.Sc., professor, chief of departement M.M. Mirsaidov*; \\ Ph.D., associate professor, vice-rector T.Z. Sultanov; \\ Ph.D., associate professor D.A. Khodzhaev, \\ Tashkent Institute of Irrigation and Melioration
}

Keywords: dynamic behavior; stress-strain state; earth dams; strength; stability; viscosity; creeping; accelerogram

\section{Introduction}

It is known that in evaluation of the strength of earth structures an account of non-linear, viscoelastic properties of material is of great importance.

At present an attention is paid to the design of earth dams and the main emphasis is placed on linear elastic design of a structure [1].

In published works, concerning dynamic design of earth dams, a model of elastic-plastic body is frequently used; according to this, soil behaves as a linear-elastic body till it is reaching some limit state [2-7].

The experience of earth dams engineering and current studies show that in development of the methods of such structures' design it is necessary to account rather complex conditions of earth dams operation, their real deformation, strength and stress properties of construction itself and its material under the different loads [8].

Materials of soil, widespread at the Republic of Uzbekistan, have rheological properties (that is stress-strain relation that depends on time) [6, 7, 9]. Viscoelastic properties of soil (creeping and relaxation) appear to different degree under static and dynamic effects [9-12]. Necessity to account viscoelastic properties of soil is actual in the design and engineering of earth structures, earth dams particularly located in the zones with high seismic risk, where the structure is subjected to the intensive dynamic loads, especially in resonant and near-resonant modes of vibrations [13, 14]. At such modes of vibrations viscoelastic properties of a material due to dissipative (absorbing) properties damp undesirable vibrations of a structure.

The study of dissipative properties of structures is rather complex problem even for linear mechanical systems, as to evaluate dissipative properties of a structure it is necessary to investigate natural, steady and unsteady vibrations of a structure with account of internal friction in material. The difficulty of such solution consists, firstly, in the absence of models which more or less could correctly describe the phenomenon of the internal friction in the material. Secondly, the solution of the problem with account of known models leads to a number of problems and hardly realized even with modern PC due to the lack of computational methods and algorithms, satisfying the requirements. So, in dynamic design of concrete structures the models made by Foight, Maxwell, Kelvin, E.S. Sorokin and others are used to account the dissipative properties of material $[3,4,12,15]$.

In [16] study of non-linear dynamic processes in a dam the model is used, where dissipative components are taken directly proportional to the elements of the matrix of hardness and mass.

The behavior of concrete structures using hereditary theory of viscoelasticity in conditions of dynamic loading is less studied [7, 13]. Almost all publications connected with dynamic problems of hereditary theory of viscoelasticity are devoted to the design of (linear and geometrically non-linear) thinwalled structures: beams, plates and shells $[17,18]$.

The scheme of the solution of dynamic problems in viscoelasticity for thin-walled structures is a standard one, that is, by some approximate method (for example, Bubnov-Galerkin method) finding coordinate function satisfying boundary conditions, initial problem is reduced to the problem of vibrations of the system with finite number of degrees of freedom, that is to the system of linear or non-linear integral-differential equations with one independent variable of time [17, 18]. As a rule, here trigonometric or beam functions are used as coordinate functions. Such choice of coordinate functions restricts the class of solved problems by the structures with the simplest configurations - beams with constant section, rectangular plates, cylinder shells $[17,18]$. The authors, assuming a number of inaccuracies in a Mirsaidov M.M., Sultanov T.Z., Khodzhaev T.A. Stability evaluation of slopes of earth dams with account of soil rheological properties 
selection of coordinate functions, try to increase the accuracy in solving the system of integral-differential equations. However, it is impossible for structures with real geometry to pick out analytical coordinate functions, satisfying boundary conditions of the problem,

In $[13,14]$ the natural vibrations of a certain structure, calculated by the method of finite elements are used as coordinate functions; they allow to account both the real geometry and the conditions of structure operation. Forced vibrations of some types of the earth structures were studied and the effect of viscoelastic properties of material on the amplitude of structure vibration at a resonant mode was assessed.

It is known, that considerable change in behavior of the earth structures is possible under the effect of mean intensity, when viscoelastic properties of soil are seen even at small deformations [12, 19-21].

In study [22] rheological properties of soil are studied to determine its viscosity depending on stress value and to obtain information on the effect of viscosity of material in evaluation of landslides hazards.

In study [23] a mathematical model was worked out and the methods were offered to assess stress-strain state of viscoelastic water-saturated foundations of structures after the termination of the observed process of filtration consolidation. Calculation of the structure settlement was done with account of viscoelastic properties of foundation material.

A neglect of viscoelastic properties of material in design and projecting of particularly important structures, such as earth dams, may lead to the incorrect assessment of their strength. To predict some geological damage in soils a viscoelastic dynamic model of soil was offered and a new equation was written, which accounts viscous-plastic properties of soil [24].

In [25] a numeric model was offered to study rock mass, quickly moving down inclined area. In this model rheological properties of soil are considered; they allow selecting the multiple rheological correlations, the change in the rheology of flow with time, anisotropic distribution of stress, etc. Reliability of such model was proved by solution of different comparable examples.

The review of publications given above shows that the problem of account of soil inelastic properties in dynamic design of structures and mechanical effects appearing in them under different effects was not widely studied and described in literature.

\section{Mathematical statement, method and algorithm of the problem solution}

\subsection{Statement of the problem}

In statement of the dynamic problem of forced vibrations of the earth structure (Fig.1), consisting of deformable bodies with volume $V=V_{1}+, \ldots,+V_{5}$, operating in conditions of plane deformation, it is taken, that the foundation of structure $\Sigma_{u}$ is subjected to arbitrary kinematic effect $\vec{u}_{0}\left(x_{1}, x_{2}, t\right)$. On the surface $S_{p}$ hydrostatic pressure of water $\vec{p}_{c}\left(x_{1}, x_{2}\right)$ is applied, the rest part of the surface is free from stresses. The structure presents massive body, so mass forces $\vec{f}$ are taken into consideration in design. Material of different parts of a structure is considered to be linear elastic and viscoelastic. On the borders of division of displacements the components of the tensor of stresses are continuous.

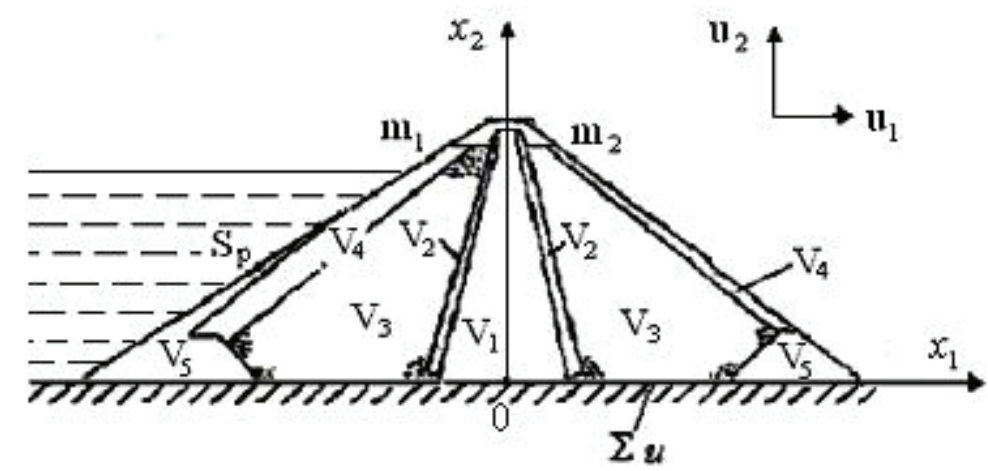

Figure 1. Design model of structure

Mirsaidov M.M., Sultanov T.Z., Khodzhaev T.A. Stability evaluation of slopes of earth dams with account of soil rheological properties 
The problem consists in determination of the fields of displacements and stresses in a structure (Fig. 1), with account of mass forces $\vec{f}$, water pressure $\vec{p}_{c}\left(x_{1}, x_{2}\right)$ and kinematic effect in the foundation $\vec{u}_{0}\left(x_{1}, x_{2}, t\right)$.

The principle of possible displacements is used in the statement of the problem; according to it, the sum of works of all active forces, including inertia forces, on possible displacements equals to zero:

$$
\delta A=-\int_{V} \sigma_{i j} \delta \varepsilon_{i j} d V-\int_{V} \rho_{n} \ddot{\vec{u}} \delta \vec{u} d V+\int_{V} \vec{f} \delta \vec{u} d V+\int_{S_{P}} \vec{p}_{c} \delta \vec{u} d S=0 .
$$

Here $\vec{u}, \varepsilon_{i j}, \sigma_{i j}$ - vector of displacements and components of tensors of strains and stresses respectively; $\delta \vec{u}, \delta \varepsilon_{i j}$ - isochronic variations of displacements and strains; $\rho_{n}$ - density of material of the elements of a structure $\vec{f}$ - vector of mass forces; $\vec{p}_{c}$ - hydrostatic pressure of water. used [26]

To describe the properties of viscoelastic material Boltsmann-Volterra's linear hereditary model is

$$
\begin{gathered}
\sigma_{i j}=\sigma \delta_{i j}=2 G_{n}\left[\left(\varepsilon_{i j}(t)-\frac{\theta(t)}{3} \delta_{i j}\right)-\int_{0}^{t} R_{n}(t-\tau)\left(\varepsilon_{i j}(\tau)-\frac{\theta(\tau)}{3} \delta_{i j}\right) d \tau\right] . \\
\sigma=K_{n} \theta, \sigma=\frac{1}{3} \sigma_{k k}, \theta=\varepsilon_{k k}, i, j, k=1,2 .
\end{gathered}
$$

In (2) the following designations are used: $K_{n}, G_{n}$-instantaneous volume and shear modulus of elasticity; $R_{n}$ - relaxation kernel to account viscous properties of material; $\delta_{i j}$ - Kronekker's symbol; $\theta$ - volume deformation. Where an index $n=1, \ldots, 5$ refers to corresponding volume $V_{n}$.

Connection of strain with the components of displacement is described by linear Cauchy's relations

$$
\varepsilon_{i j}=\frac{1}{2}\left(\frac{\partial u_{i}}{\partial x_{j}}+\frac{\partial u_{j}}{\partial x_{i}}\right), i, j=1,2 \text {. }
$$

Kinematic conditions in the foundation are given in the form

$$
\vec{x} \in \Sigma_{0}: \vec{u}_{0}(\vec{x}, t)=\vec{\psi}_{1}(t),
$$

and boundary conditions at $t=0$ :

$$
\vec{x} \in V: \vec{u}(\vec{x}, 0)=\vec{\psi}_{2}(\vec{x}) ; \quad \dot{\vec{u}}(\vec{x}, 0)=\vec{\psi}_{3}(\vec{x}),
$$

where $\vec{\psi}_{1}$ - is a given function of time; $\vec{\psi}_{2}, \vec{\psi}_{3}$ - given functions of coordinates.

Vector of displacements has two components $\vec{u}=\left\{u_{1}, u_{2}\right\}$ in the system of coordinates $\vec{x}=\left\{x_{1}, x_{2}\right\}$.

So, general variation problem of forced vibrations consists in determination of the fields of displacements $\vec{u}(\vec{x}, t)$ and stresses $\sigma_{i j}(\vec{x}, t)$ of deformable structure (Fig.1), satisfying the equations (1)-(3), with account of mass forces $\vec{f}$, hydrostatic pressure of water $\vec{p}_{c}$, kinematic and initial conditions (4), (5) at any possible displacement $\delta \vec{u}$.

Mirsaidov M.M., Sultanov T.Z., Khodzhaev T.A. Stability evaluation of slopes of earth dams with account of soil rheological properties 


\subsection{Method and algorithm of solution of the problem}

Solution of variation problem (1)-(5) is found in the following form [13]:

$$
\vec{u}(\vec{x}, t)=\vec{u}_{o}(\vec{x}, t)+u^{*}(\vec{x}, t) .
$$

Here $\vec{u}^{*}(\vec{x}, t)$ - a vector of detected displacements.

The use of the method of finite elements $[7,27]$ brings discussed problem to the solution of the system of linear integral differential equations of $\mathrm{N}$-order

$$
[M]\{\ddot{u}(t)\}+[C]\{\dot{u}(t)\}+[K]\{u(t)\}=\{F\}+\{f(t)\}+\int_{0}^{t} \Gamma(t-\tau)[K]\{u(\tau)\} d \tau
$$

with initial conditions

$$
\{u(0)\}=\left\{u_{0}\right\},\{\dot{u}(0)\}=\left\{v_{0}\right\} .
$$

Here matrices $[M],[K]$ are matrices of mass and rigidity of the whole structure; $[C]$ - matrix of dissipation, if friction in material is also taken into consideration; $\{u(t)\}$ - vector of detected amplitudes of displacements; $\{f(t)\}$ - vector of external load from kinematic effect; $\{F\}$ - summed vector of external loads (mass forces, hydrostatic pressure of water and other).

Equation (7) with given initial conditions (8) is solved by the method of direct integration with stepby-step numeric Newmark's method [7, 27], adapted to the solution of the system of integral-differential equations.

Using Newmark's method, the system of integral-differential equations may by reduced to algebraic system of equations

$$
[A]\left\{u_{i+1}\right\}=\left\{R_{i+1}\right\}
$$

where

$$
[A]=[K]+\frac{1}{\alpha \Delta t^{2}}[M]+\frac{\beta}{\alpha \Delta t}[C] .
$$

Here the right part of equation (9) would be:

$$
\begin{aligned}
& \left\{R_{i+1}\right\}=\left\{f\left(t_{i+1}\right)\right\}+\{F\}+[M]\left(\frac{1}{\alpha \Delta t^{2}}\left\{u_{i}\right\}+\frac{1}{\alpha \Delta t}\left\{\dot{u}_{i}\right\}+\left(\frac{1}{2 \alpha}-1\right)\left\{\ddot{u}_{i}\right\}\right)+ \\
& +[C]\left(\frac{\beta}{\alpha \Delta t}\left\{u_{i}\right\}+\left(\frac{\beta}{\alpha}-1\right)\left\{\dot{u}_{i}\right\}+\frac{\Delta t}{2}\left(\frac{\beta}{\alpha}-2\right)\left\{\ddot{u}_{i}\right\}\right)+\int_{0}^{t_{i+1}} R(t-\tau)[K]\left\{u_{i}\right\} d \tau
\end{aligned}
$$

Newmark's method is absolutely stable, if $\beta \geq 0.5, \alpha \geq 0,25(\beta+0,5)^{2}$.

So, the solution of the system of integral-differential equations (7) with initial conditions (8) consists in the following:

Initial conditions $\left\{u_{0}\right\},\left\{\dot{u}_{0}\right\},\left\{\ddot{u}_{0}\right\}=0$ are given.

The system of algebraic equations (9) and (10) is formed; the right part (11) contains integral items, which describe viscous properties of a material, dependent on reached stressed state of a system.

Singularity of the algorithm is the fact, that the integrals, entering the expression (11), are computed from the beginning of the process, while on each step the integrals are defined within the limits from $t_{i}$ till $t_{i+1}$. Here a full value of integral items at the moment of time $t_{i+1}$ is obtained as a result of summing up of saved on previous step value with the value of integral, obtained on the last stage with integration limits from $t_{i}$ till $t_{i+1}$. 
To realize above discussed problems and algorithms, PC programs were worked out, proved by patents of State Patent Department of the Republic of Uzbekistan (No. DGU 01537, 19.06.2008 and No. DGU 02137, 31.01.2011).

\subsection{Test example}

To confirm reliability of worked out algorithms and design programs, Newmark's method was used for solving the integral differential equations

$$
\ddot{y}(t)+\omega^{2}\left[y(t)-\int_{0}^{t} R(t-\tau) y(\tau) d \tau\right]=f(t)
$$

at initial conditions

$$
y(0)=1, \dot{y}(0)=-\beta
$$

and initial data

$$
\begin{gathered}
R(t)=A e^{-\beta t} \cdot t^{\alpha-1}, \\
f(t)=\left[\beta^{2}+\omega^{2}-\frac{A \omega^{2} t^{\alpha}}{\alpha}\right] e^{-\beta t}, \\
A=0,01 ; \alpha=0,25 ; \omega=2 \pi ; \beta=0,05
\end{gathered}
$$

Equation (12) at initial conditions (13) has an exact solution [17]: $y=e^{-\beta t}$.

Table 1 gives results of exact solution [17] of equations (12) with initial conditions (13) and solutions, obtained with worked out algorithm at different values of $t$.

Table 1. Comparison of approximate solution with exact one

\begin{tabular}{|l|c|c|c|c|c|c|c|c|c|c|}
\hline Time, t, sec & 0,4 & 1,2 & 2,0 & 4,0 & 8,0 & 12,0 & 16,0 & 20,0 & 24,0 & 28,0 \\
\hline $\begin{array}{l}\text { Solution by Newmark's } \\
\text { method }\end{array}$ & 0,972 & 0,926 & 0,887 & 0,800 & 0,654 & 0,535 & 0,439 & 0,361 & 0,297 & 0,245 \\
\hline Exact solution & 0,980 & 0,941 & 0,904 & 0,818 & 0,670 & 0,548 & 0,449 & 0,367 & 0,301 & 0,246 \\
\hline
\end{tabular}

\subsection{An assessment of strength}

An assessment of strength in each point of the structure is performed according to the value of coefficient of safety factor $K[28,29]$, defined by the formula

$$
K=\frac{0,5\left(\sigma_{11}+\sigma_{22}\right) \sin \varphi+C \cdot \cos \varphi}{0,5 \sqrt{\left(\sigma_{11}+\sigma_{22}\right)^{2}+4 \sigma_{12}^{2}}} .
$$

Here $\sigma_{i j}$ - full (static and dynamic) stresses in the point $(i, j=1,2) ; \varphi, C$ - an angle of internal friction and coefficient of soil cohesion, respectively.

Complete pattern of distribution of values of coefficient $K$ along the whole structure, including slope zones of a dam, permits to state the presence, dimensions and location of zones, where one of three following conditions is satisfied:

- $K>1$ - in this part of a structure soil will possess safety factor, that is the structure is in prelimit state;

- $K=1-$ soil is in condition of limit balance;

- $K<1-$ soil strength in this area is damaged and zone of instability is formed.

The values of coefficient of strength $K$ with known stressed state in different points of soil mass, permit to perform unique checkout of limit state and to determine the location of sliding areas.

Mirsaidov M.M., Sultanov T.Z., Khodzhaev T.A. Stability evaluation of slopes of earth dams with account of soil rheological properties 


\section{Results of the study}

Dynamic behavior and stress-strain state of several models of earth dams with heights from $70 \mathrm{~m}$ up to $296 \mathrm{~m}$ were studied with account of their constructive features. Here for different parts of a dam corresponding elastic and viscoelastic properties of soil were taken into consideration.

To describe viscoelastic properties of soil three-parametric kernels (14) of relaxation [30] were used with parameters $(A, \alpha, \beta)$, determined from creep curves [10,11] of soils according to methods [31]. The values of kernel parameters $(A, \alpha, \beta)$ determined for different soils, are given in [7].

\subsection{Steady forced vibrations}

Study of steady forced vibrations of the model of Zaamin earth dam with height $H=73 \mathrm{~m}$ with account of viscoelastic properties of soil was performed on periodic kinematic effect

$$
\vec{x} \in \Sigma_{u}: \begin{aligned}
& u_{0}(t)=A \exp (-i p t) \\
& \mathrm{v}_{0}(t)=B \exp (-i p t)
\end{aligned}
$$

In constructive relation this dam has a reflecting screen made of loamy soils, located parallel to upper pressure face. Coefficients of laying of slopes are: upper one $m_{1}=2.5$ and lower one $m_{2}=2.0$.

Mechanical characteristics ( $E$ - elasticity modulus, $\mu$-Poisson's coefficient, $\gamma$ - specific weight) of material: for support prisms from gravel-pebble soil $-E=3.06 \cdot 10^{5} \mathrm{tf} / \mathrm{m}^{2}, \mu=0.3, \gamma=2.1 \mathrm{t} \mathrm{f} / \mathrm{m}^{3}, \varphi=37^{0}$; for reflecting screen from loamy soil $-E=2.4 \cdot 10^{5} \mathrm{t} \mathrm{f} / \mathrm{m}^{2}, \mu=0.25, \gamma=1.7 \mathrm{t} \mathrm{f} / \mathrm{m}^{3}, \varphi=24^{0}$. Averaged coefficient of soil cohesion is $C=1.9 \mathrm{t} \mathrm{f} / \mathrm{m}^{2}\left(\mathrm{t} \mathrm{f} / \mathrm{m}^{2}\right.$ - ton force on quadratic meter, $\mathrm{t} f / \mathrm{m}^{3}-$ ton force on cubic meter).

Steady forced vibrations of earth dam were studied under external periodic effects. Here for certain points of a dam amplitude-frequency characteristics were built for displacements $u, v$ and stress components $\sigma_{11}, \sigma_{22}, \sigma_{12}$ at different frequencies " $p$ " of kinematic effect (16) with correlation A/B=2.0 in frequency range from 5 to $60 \mathrm{rad} / \mathrm{sec}$. In vicinity of assumed viscoelastic resonance, frequency step " $p$ " was 2-3 times less.

As an example amplitude-frequency characteristics for horizontal $u(-)$ and vertical $v(----)$ displacements are shown in Fig. 2a, and for horizontal normal stresses $(-)-\sigma_{11}$, vertical normal stresses (-----) $-\sigma_{22}$ (Fig. 2b) for the point of a dam A with coordinates $x_{1}=-40.1 \mathrm{~m}, x_{2}=41.7 \mathrm{~m}$.

a)

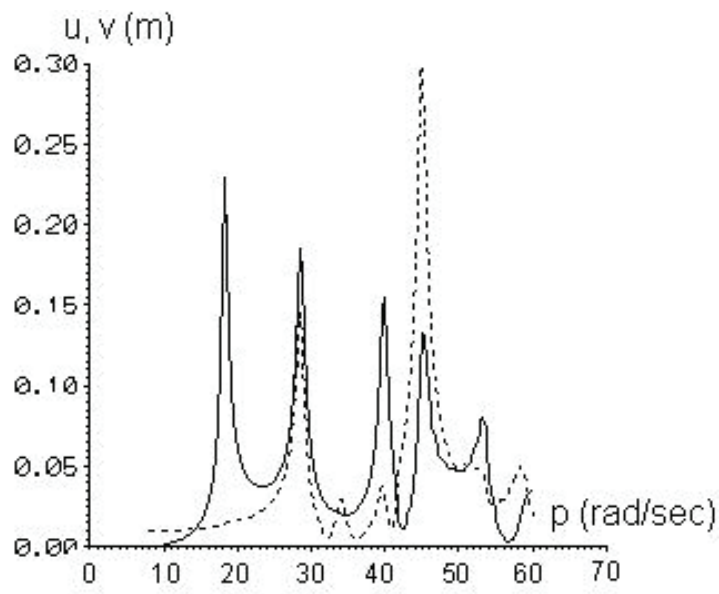

b)

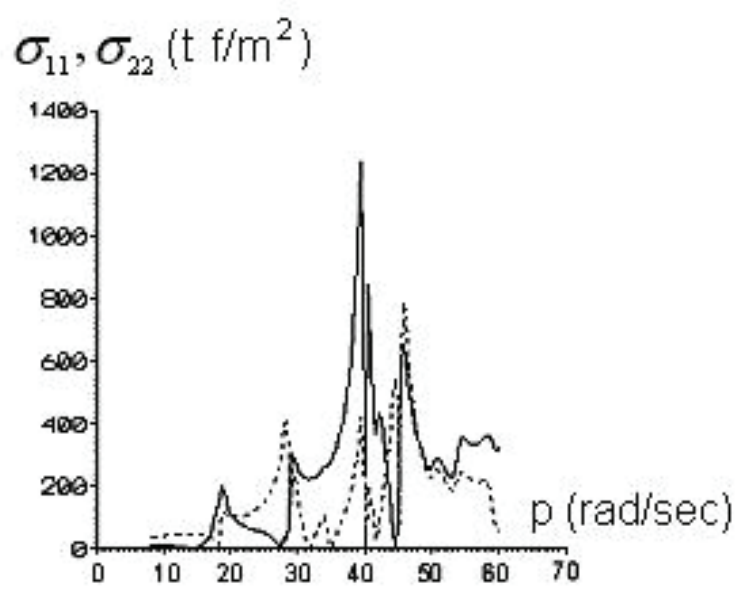

Figure 2. Amplitude-frequency characteristics of displacements and components of stresses of the point $A$ of a dam

An analysis of results revealed domination of the amplitude of horizontal vibrations at the first resonance frequency. At other resonant frequencies the amplitude of horizontal displacements significantly decreased. The greatest value of vertical displacements, on the contrary, appears at the fifth frequency. This confirms the fact that the first mode of structure vibration presents shifting with domination of horizontal displacements, while in other higher modes horizontal displacements are decreasing and are substituted by vertical ones. 
Results of analysis show that the greatest amplitudes of stresses for many parts of a dam occur at coincidence of frequency of kinematic effect $p$ with own frequency of a dense specter, in the range $\omega_{4} \div \omega_{6}$. In correlation of the modes of vibration with similar frequencies a single peak is formed with the greatest amplitudes; so for this dam the most dangerous is the value of frequency of external effect in the range between $\omega_{4}$ and $\omega_{6}$.

\subsection{Unsteady forced vibrations}

Dynamic behavior of the model of Nurek earth dam $(H=296 \mathrm{~m})$ was studied, with constructive solution shown in Fig.1, with account of elastic and viscoelastic properties of soil under different nonstationary kinematic effects in the form of acceleration of a foundation: at horizontal and vertical directions on rectangular impulse with duration $0.09-0.2 \mathrm{sec}$, with amplitude $30-500 \mathrm{~cm} / \mathrm{sec}^{2}$; at the record of actual registered accelerogram of Gazli earthquake with duration $9 \mathrm{sec}$ [32]. This dam is the highest one among earth structures, built in zones with high seismicity (magnitude 9). The dam has almost symmetrical profile and very steep slopes: upper one $-m_{1}=2.25$ and lower one $-m_{2}=2.2$. Mechanical characteristics of the material for support prisms $-E=3.06 \cdot 10^{5} \mathrm{tf} / \mathrm{m}^{2}, \mu=0.3, \gamma=2.2 \mathrm{t} f / \mathrm{m}^{3}$; for the kernel $-E=2.4 \cdot 10^{5} \mathrm{t} \mathrm{f} / \mathrm{m}^{2}, \mu=0.25, \gamma=2.33 \mathrm{t} \mathrm{f} / \mathrm{m}^{3}$.

In solution of this problem initial conditions were homogeneous. An analysis of stress-strain state of different points of a dam under the effect of accelerogram shows that for the parts located higher than $200 \mathrm{~m}$ and in slope zones of a dam, tensile dynamic stresses are greater than compressive ones (that is soil is working on tension). Evidently, this is explained by the value of acting acceleration: at the moment $t=8.423 \mathrm{sec}$ its value in the record of accelerogram goes up to $1.3 \mathrm{~g}\left(g=9.81 \mathrm{~m} / \mathrm{sec}^{2}\right)$.

In Fig. 3 distribution of isolines of basic stresses $\sigma_{1}$ under the effect of accelerogram of ground motion at the moment $t=8.439 \mathrm{sec}$ is shown.

An analysis of obtained isolines of equal levels of main stresses shows that the greatest tensile stresses $\left(\sigma_{1}\right)$ occur in the middle of upper slope of a dam. In upper part of a kernel and in the middle of upper and lower slopes there appear the areas with sufficiently large values of maximal tangential stresses $\left(\tau_{\max }\right)$. The greatest values of tensile stresses $\left(\sigma_{2}\right)$ appear in a lower part of a kernel and in lower part of lower slope. In some sections of upper slope there appear sufficiently large maximal tengential stresses, undesireable in earth dams. The presence in a dam of sections (Fig. 3) with large tensile stresses $\sigma_{1}$ exceeding the values of negative (tensile stresses) $\sigma_{1}$, appearing under static effects (under the action of own weight), may lead to a damage of stability of these sections.

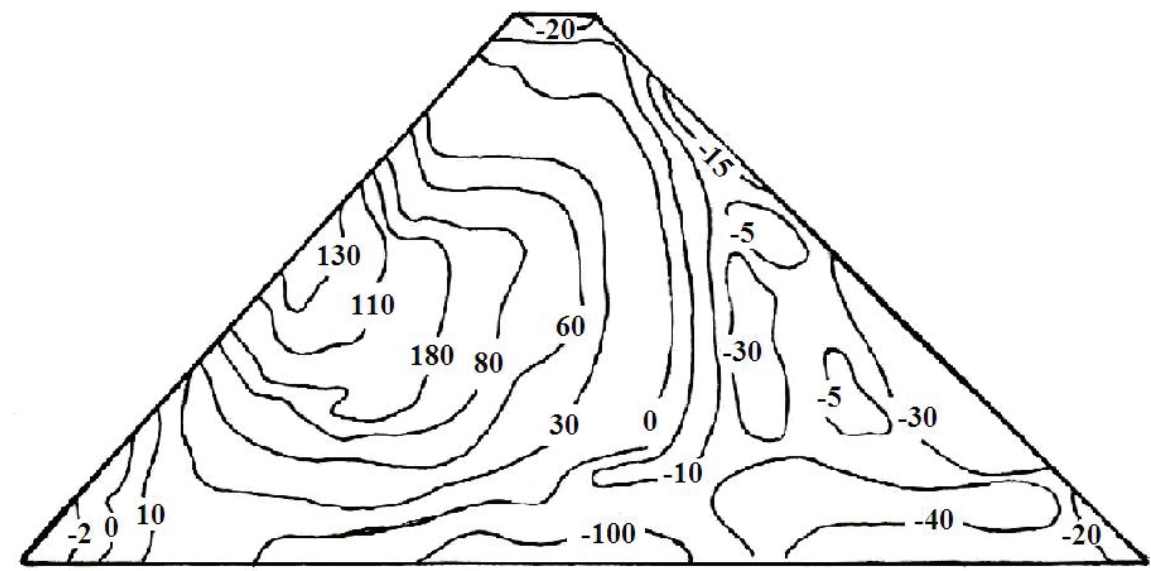

Figure 3. Distribution of isolines of main stress $\sigma_{1}\left(t \mathrm{f} / \mathrm{m}^{2}\right)$ in the section of a dam at $t=8.439 \mathrm{sec}$ under the effect of accelerogram

Stress-strain state of the model of Ghissarak earth dam $(H=138 \mathrm{~m})$ was studied with account of elastic and viscous-plastic properties of soil, heterogeneity and own weight of a structure under the effect of horizontal rectangular impulse of acceleration with amplitude $200 \mathrm{~cm} / \mathrm{sec}^{2}$. The dam has the slopes: upper one $-m_{1}=2.2$ and lower one $-m_{2}=1.9$. Mechanical characteristics of material are: for support prisms $-E=3.6 \cdot 10^{5} \mathrm{t} \mathrm{f} / \mathrm{m}^{2}, \mu=0.26, \gamma=1.90 \mathrm{t} \mathrm{f} / \mathrm{m}^{3}$; for kernel $-E=2.4 \cdot 10^{5} \mathrm{tf} / \mathrm{m}^{2}, \mu=0.35, \gamma=1.7 \mathrm{tf} / \mathrm{m}^{3}$.

Mirsaidov M.M., Sultanov T.Z., Khodzhaev T.A. Stability evaluation of slopes of earth dams with account of soil rheological properties 
Distribution of isolines of coefficient of safety strength $K$ is shown in Fig.4 in the section of Ghissarak dam, obtained with account of heterogeniety, own weight and under the effect of horizontal rectangular impulse of acceleration.

An analysis of the study permits to reveal unstable zones (from a strength point of view) in a dam. Investigation results of stress-strain state of Ghissarak dam show considerable change in vertical stresses and the intensity of stresses, which lead to an occurrence of an arch effect. The occurrence of arch effect in cross section of a dam on the contact of a kernel with transient zones and prisms under kinematic effect (expressed in sharp drop of stresses in a kernel and their increase in transient zones) is explained by the difference of deformability of materials of loamy sand of a kernel and support prisms. Such phenomena may lead to probable damage of monolithic character of a dam with formation of through cross fractures inside and longitudinal fractures on the crest of a kernel.

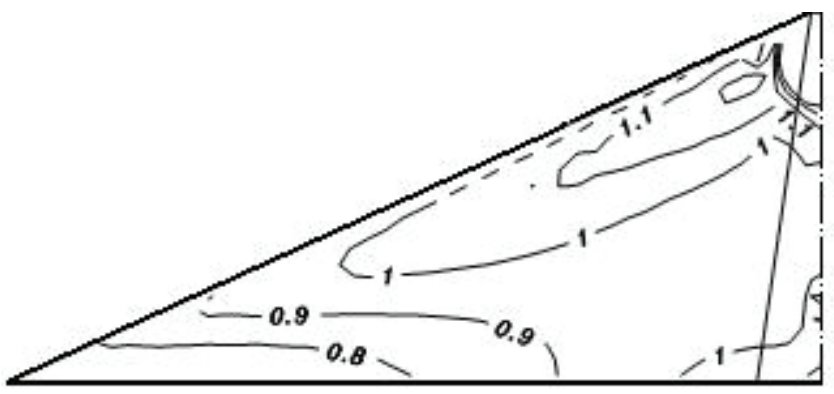

\section{Figure 4. Distribution of isolines of coefficient of safety strength $K$ in a section of support prism of heterogeneous Ghissarak dam}

An analysis of obtained distribution of coefficient of safety strength shows that at given constructive solutions of a structure, namely, at flat slopes the value of coefficient $K$ is more than 1 , which points on stability of slopes along the height of a structure, if stress-strain state was formed under own weight only. Inertia forces, appearing in a structure under horizontal seismic effect, form considerable additional stress state in a structure. Due to it the strength on certain sections of a dam is damaged (Fig.4), in particular, in lower part of upper support prism from slope zones inside the depth of a dam, where the value of coefficient of safety strength is $K<1$, that is unstable (from the point of view of strength) zone is seen.

\section{Conclusion}

1. Numeric model, algorithm and program of dynamic design of earth dams on PC were worked out with the use of Boltsmann-Volterra linear hereditary theory and Rjanitsin's kernel of relaxation with account of heterogeneity of structure.

2. Reliability of worked out algorithms and design programs was proved by solution of test problems.

3. According to results obtained one may draw the following conclusions:

- under dynamic effects with different frequencies the greatest horizontal displacement is observed at the first, and vertical - at higher resonance frequencies;

- the greatest amplitudes of stresses in the body of a dam appear at coincidence of the frequencies of external effects with natural frequencies of a dense specter from $\omega_{4}$ to $\omega_{6}$;

- long-term dynamic effect leads with time to occurrence of dangerous tensile stresses in certain zones of a dam; an account of viscosity - to gradual damping of vibrations with time;

- maximal values of normal and tangential stresses under short-term kinematic effect are reached in different points of a dam: vertical ones - in the foundation, horizontal - on slopes, tangential - in upper part of a kernel;

- stress-strain state of a structure is subjected not only to intensity of acceleration, but in a greater degree to its frequency specter and duration of the effect;

- an account of heterogeneity of a structure leads to strengthening of arch effect in kernel zone, characteristic for vertical stresses; this is due to the difference of deformation properties of soils of a kernel and prisms;

- under strong ground motions (Gazli earthquake) in the most parts of earth dams there appear great tensile dynamic stresses.

Mirsaidov M.M., Sultanov T.Z., Khodzhaev T.A. Stability evaluation of slopes of earth dams with account of soil rheological properties 


\section{References}

1. Mirsaidov M.M. Problemy mekhaniki. 2010. №2. Pp. 12-16. (rus)

2. Didukh B.I. Dinamika sploshnykh sred $v$ raschetakh gidrotekhnicheskikh sooruzheniy [Dynamics of Solids in Design of Hydrotechnical structures]. Moscow.:Energiya, 1976. 391 p. (rus)

3. Krasnikov N.D. Seysmostoykost gidrotekhnicheskikh sooruzheniy iz gruntovykh materialov [Seismic Stability of Hydro-technical Structures from Soil Materials]. Moscow: Energoizdat, 1981. 240 p. (rus)

4. Lyakhter B.M., Ivashchenko I.N. Seysmostoykost gruntovykh plotin [Seismic Stability of Earth Dams]. Moscow: Nauka, 1986. 233 p. (rus)

5. Salyamova K.D. Problemy mekhaniki. 2003. №4. Pp. 12-15. (rus)

6. Mirsaidov M.M., Godovannikov A.M. Seysmostoykost sooruzheniy [Seismic Stability of Structures]. Tashkent: Uzbekistan, 2008. 220 p. (rus)

7. Mirsaidov M.M. Teoriya i metody rascheta gruntovykh sooruzheniy na prochnost i seysmostoykost.[Theory and Methods of Design of Earth Structures on Strength and Seismic Stability]. Tashkent: FAN, 2010. 312 p. (rus)

8. Mirsaidov M.M., Rumi D.F. Vestnik Tashkentskogo instituta inzhenerov transporta. 2007. №3-4. Pp. 41-48. (rus)

9. Shirinkulov T.Sh., Zaretsky Yu.K. Polzuchest i konsolidatsiya gruntov [Creeping and Consolidation of Soils]. Tashkent: Fan, 1986. 302 p. (rus)

10. Vyalov S.S. Reologicheskiye osnovy mekhaniki gruntov [Rheological Basis of the Mechanics of Soil]. Moscow: Vysshaya shkola, 1978. 447 p. (rus)

11. Meschyan S.R. Mekhanicheskiye svoystva gruntov i laboratornyye metody ikh opredeleniya [Mechanical Characteristics of Soils and Laboratory Methods of Their determination]. Moscow: Nedra, 1974. 192 p. (rus)

12. Krasnikov N.D. Dinamicheskiye svoystva gruntov i metod ikh opredeleniya [Dynamic properties of Soils and the Method of Their Determination]. Leninrad: Stroyizdat, 1970. 239 p. (rus)

13. Mirsaidov M.M., Troyanovskiy E.I. Dinamika neodnorodnykh sistem s uchetom vnutrenney dissipatsii $i$ volnovogo unosa energii [Dynamics of Inhomogeneous Systems with Account of Internal Dissipation and Wave Transfer of Energy]. Tashkent: FAN, 1990. 108 p. (rus)

14. Mirsaidov M.M. Seismic stability of different earth dams. (2011). $6^{\text {th }}$ International Conference on Dam Engineering. 15-17 February 2011. LNEC. Lisbon, Portugal. Pp.787-798.

15. Potapov A.N. Metod vremennogo analiza reaktsii diskretnykh dissipativnykh sistem $v$ zadachakh stroitelnoy mekhaniki [Method of temporal Analysis of Reaction of Descrete Dissipative Systems in Problems of Engineering Mechanics]. Ph.D. dissertation. Chelyabinskк, 2003. 261 p. (rus)

16. Xiong B.-L., Wang X.-L., Lu Ch.-J. Dynamic Reaction Analysis of Tailing Dams Under Earthquake. Advances in Environmental Geotechnics. 2010. No.6. Pp. 697-701.

17. Badalov F.B. Metody resheniya integralnykh i integrodifferentsialnykh uravneniy nasledstvennoy teorii vyazkouprugosti [Methods of Solution of Integral and Integral-Differential Equations of Hereditary Theory of Viscous-Elastisity]. Tashkent: Mekhnat, 1987. 269 p. (rus)

18. Abdikarimov R.A., Eshmatov Kh. et al.. Magazine of Civil Engineering. 2011. № 3. Pp. 59-70. (rus)

19. Sultanov K.S., Khusanov B.E. Problemy mekhaniki. 2004. №5-6. Pp. 27-31. (rus)

20. Khusanov B.E. Doklady AN RUz. 2004. №2. Pp. 35-40. (rus)

21. Bauer E., Fu Z.Z., Liu S. Constitutive Modeling of Rheological Properties of Materials for Rockfill Dams. $6^{\text {th }}$ International Conference on Dam Engineering. 15-17 February 2011. LNEC. Lisbon, Portugal. Pp. 1-14.

22. Bisantino T., Fischer P., Gentile F. Rheological characteristics of debris-flow material in South-Gargano watersheds. Natural Hazards. 2010. №54(2). Pp. 209-223.

23. Emelyanova T.V. Matematicheskoye modelirovaniye napryazhenno-deformirovannogo sostoyaniya vyazkouprugikh vodonasyshchennykh osnovaniy [Mathematical Modeling of Stress-Strain State of Viscous-elastic Water Saturated Foundations]. Ph.D. dissertation. Tyumen, 2009. 162 p. (rus)

Mirsaidov M.M., Sultanov T.Z., Khodzhaev T.A. Stability evaluation of slopes of earth dams with account of soil rheological properties 
24. Hu H., Gu H., Yu D. The Research on Dynamic Rheological Mechanical Response and Rheological Dynamic Model of Geological Disaster of Soft Rock-Soil. Geotechnical Engineering for Disaster Mitigation and Rehabilitation. 2008. Part 4. Pp. 359-366.

25. Hungr O. Numerical modeling of the motion of rapid, flow-like landslides for hazard assessment. KSCE Journal of Civil Engineering. 2009. №13(4). Pp. 281-287.

26. Ilyushin A.A., Pobedrya B.E. Osnovy matematicheskoy teorii termo-vyazkouprugosti [Basis of Mathematical Theory of Thermal-viscous-elastisity]. Moscow: Nauka, 1970. 280 p. (rus)

27. Bate K., Wilson E. Chislennyye metody analiza i MKE [Numeric Methods of Analysis and the Method of Finite Elements]. Moscow: Stroyizdat, 1982. 448 p. (rus)

28. Tsitovich N.A., Ter-Martirosyan Z.G. Osnovy prikladnoy geomekhaniki v stroitelstve [Grounds of Applied Geomechanics in Engineering]. Moscow: Vysshaya shkola, 1981. 317 p. (rus)

29. Mirsaidov M.M., Sultanov T.Z., Rumi D.F. Materialy Mezhdunarodnoy nauchno-tekhnicheskoy konferentsii, posvyashchennoy 70-letiyu akademika T.Sh.Shirinkulova [Proc. Of International scientifictechnical conference, devoted to academician T.Sh.Shirinkulov's seventieth anniversary]. Samarkand, 2007. Vol. 4. Pp. 38-44. (rus)

30. Rzhanitsyn A.R. Teoriya polzuchesti [Theory of Creeping]. Moscow: Stroyizdat, 1968. 416 p. (rus)

31. Koltunov M.A. Polzuchest i relaksatsiya [Creeping and Relaxation]. Moscow: Visshaya shkola, 1976. 277 p. (rus)

32. Shteynberg V.V., Pletnev K.T., Grayzer V.M. Seysmostoykoye stroitelstvo. 1977. №1. Pp. 45-61. (rus)

*Mirziyod Mirsaidov, Tashkent, Uzbekistan

+998(71)237-09-81; e-mail: theormir@mail.ru, utmn@tps.uz

(C) Mirsaidov M.M., Sultanov T.Z., Khodzhaev T.A., 2012

Mirsaidov M.M., Sultanov T.Z., Khodzhaev T.A. Stability evaluation of slopes of earth dams with account of soil rheological properties 


\title{
Stability evaluation of slopes of earth dams with account of soil rheological properties
}

\author{
M.M. Mirsaidov, T.Z. Sultanov, D.A. Khodzhaev, \\ Tashkent Institute of Irrigation and Melioration, Tashkent, Uzbekistan \\ +998(71)237-09-81; e-mail: theormir@mail.ru
}

\section{Key words}

dynamic behavior; stress-strain state; earth dams; strength; stability; viscosity; creeping; accelerogram

\section{Abstract}

Numeric model, methods and algorithm to evaluate the strength of earth dams were developed in the paper using Boltzmann-Volterra hereditary theory of viscoelasticity and Rzhanitsyn relaxation kernel.

The estimated results of stress-strain state and strength of earth dams under dynamic effects are considered. The basis of this method is finite-element discretization of structure's model, which leads to solvable system of integral differential equations and further to step-by-step method of its solution.

Reliability of worked out algorithms and programs of design was checked by test examples. Study results of stress-strain state of three (different in height) dams under various effects permit to obtain stresses appearing in them and to reveal the most stressed parts of the structure in both resonant and above resonant modes.

\section{References}

1. Mirsaidov M.M. Problemy mekhaniki. 2010. No. 2. Pp. 12-16. (rus)

2. Didukh B.I. Dinamika sploshnykh sred v raschetakh gidrotekhnicheskikh sooruzheniy [Dynamics of Solids in Design of Hydrotechnical structures]. Moscow.:Energiya, 1976. 391 p. (rus)

3. Krasnikov N.D. Seysmostoykost gidrotekhnicheskikh sooruzheniy iz gruntovykh materialov [Seismic Stability of Hydro-technical Structures from Soil Materials]. Moscow: Energoizdat, 1981. 240 p. (rus)

4. Lyakhter B.M., Ivashchenko I.N. Seysmostoykost gruntovykh plotin [Seismic Stability of Earth Dams]. Moscow: Nauka, 1986. 233 p. (rus)

5. Salyamova K.D. Problemy mekhaniki. 2003. No. 4. Pp. 12-15. (rus)

6. Mirsaidov M.M., Godovannikov A.M. Seysmostoykost sooruzheniy [Seismic Stability of Structures]. Tashkent: Uzbekistan, 2008. 220 p. (rus)

7. Mirsaidov M.M. Teoriya i metody rascheta gruntovykh sooruzheniy na prochnost i seysmostoykost [Theory and Methods of Design of Earth Structures on Strength and Seismic Stability]. Tashkent: FAN, 2010. 312 p. (rus)

8. Mirsaidov M.M., Rumi D.F. Vestnik Tashkentskogo instituta inzhenerov transporta. 2007. No. 3-4. Pp. 41-48. (rus)

9. Shirinkulov T.Sh., Zaretsky Yu.K. Polzuchest $i$ konsolidatsiya gruntov [Creeping and Consolidation of Soils]. Tashkent: Fan, 1986. 302 p. (rus)

10. Vyalov S.S. Reologicheskiye osnovy mekhaniki gruntov [Rheological Basis of the Mechanics of Soil]. Moscow: Vysshaya shkola, 1978. 447 p. (rus)

11. Meschyan S.R. Mekhanicheskiye svoystva gruntov i laboratornyye metody ikh opredeleniya [Mechanical Characteristics of Soils and Laboratory Methods of Their determination]. Moscow: Nedra, 1974. 192 p. (rus)

12. Krasnikov N.D. Dinamicheskiye svoystva gruntov i metod ikh opredeleniya [Dynamic properties of Soils and the Method of Their Determination]. Leninrad: Stroyizdat, 1970. 239 p. (rus)

13. Mirsaidov M.M., Troyanovskiy E.I. Dinamika neodnorodnykh sistem s uchetom vnutrenney dissipatsii $i$ volnovogo unosa energii [Dynamics of Inhomogeneous Systems with Account of Internal Dissipation and Wave Transfer of Energy]. Tashkent: FAN, 1990. 108 p. (rus)

14. Mirsaidov M.M. Seismic stability of different earth dams. $6^{\text {th }}$ International Conference on Dam Engineering. 15-17 February 2011. LNEC. Lisbon, Portugal. Pp. 787-798.

Mirsaidov M.M., Sultanov T.Z., Khodzhaev D.A. Stability evaluation of slopes of earth dams with account of soil rheological properties 
15. Potapov A.N. Metod vremennogo analiza reaktsii diskretnykh dissipativnykh sistem $v$ zadachakh stroitelnoy mekhaniki [Method of temporal Analysis of Reaction of Descrete Dissipative Systems in Problems of Engineering Mechanics]. Ph.D. dissertation. Chelyabinskк, 2003. 261 p. (rus)

16. Xiong B.-L., Wang X.-L., Lu Ch.-J. Dynamic Reaction Analysis of Tailing Dams Under Earthquake. Advances in Environmental Geotechnics. 2010. No. 6. Pp. 697-701.

17. Badalov F.B. Metody resheniya integralnykh i integrodifferentsialnykh uravneniy nasledstvennoy teorii vyazkouprugosti [Methods of Solution of Integral and Integral-Differential Equations of Hereditary Theory of Viscous-Elastisity]. Tashkent: Mekhnat, 1987. 269 p. (rus)

18. Abdikarimov R.A., Eshmatov Kh. et al. Magazine of Civil Engineering. 2011. No. 3. Pp. 59-70. (rus)

19. Sultanov K.S., Khusanov B.E. Problemy mekhaniki. 2004. No. 5-6. Pp. 27-31. (rus)

20. Khusanov B.E. Doklady AN RUz. 2004. No. 2. Pp. 35-40. (rus)

21. Bauer E., Fu Z.Z., Liu S. Constitutive Modeling of Rheological Properties of Materials for Rockfill Dams. $6^{\text {th }}$ International Conference on Dam Engineering. 15-17 February 2011. LNEC. Lisbon, Portugal. Pp. 1-14.

22. Bisantino T., Fischer P., Gentile F. Rheological characteristics of debris-flow material in SouthGargano watersheds. Natural Hazards. 2010. No. 54(2). Pp. 209-223.

23. Emelyanova T.V. Matematicheskoye modelirovaniye napryazhenno-deformirovannogo sostoyaniya vyazkouprugikh vodonasyshchennykh osnovaniy [Mathematical Modeling of Stress-Strain State of Viscous-elastic Water Saturated Foundations]. Ph.D. dissertation. Tyumen, 2009. 162 p. (rus)

24. Hu H., Gu H., Yu D. The Research on Dynamic Rheological Mechanical Response and Rheological Dynamic Model of Geological Disaster of Soft Rock-Soil. Geotechnical Engineering for Disaster Mitigation and Rehabilitation. 2008. Part 4. Pp. 359-366.

25. Hungr $O$. Numerical modeling of the motion of rapid, flow-like landslides for hazard assessment. KSCE Journal of Civil Engineering. 2009. No. 13(4). Pp. 281-287.

26. Ilyushin A.A., Pobedrya B.E. Osnovy matematicheskoy teorii termo-vyazkouprugosti [Basis of Mathematical Theory of Thermal-viscous-elastisity]. Moscow: Nauka, 1970. 280 p. (rus)

27. Bate K., Wilson E. Chislennyye metody analiza i MKE [Numeric Methods of Analysis and the Method of Finite Elements]. Moscow: Stroyizdat, 1982. 448 p. (rus)

28. Tsitovich N.A., Ter-Martirosyan Z.G. Osnovy prikladnoy geomekhaniki v stroitelstve [Grounds of Applied Geomechanics in Engineering]. Moscow: Vysshaya shkola, 1981. 317 p. (rus)

29. Mirsaidov M.M., Sultanov T.Z., Rumi D.F. Materialy Mezhdunarodnoy nauchno-tekhnicheskoy konferentsii, posvyashchennoy 70-letiyu akademika T.Sh.Shirinkulova [Proc. Of International scientific-technical conference, devoted to academician T.Sh.Shirinkulov's seventieth anniversary]. Samarkand, 2007. Vol. 4. Pp. 38-44. (rus)

30. Rzhanitsyn A.R. Teoriya polzuchesti [Theory of Creeping]. Moscow: Stroyizdat, 1968. 416 p. (rus)

31. Koltunov M.A. Polzuchest i relaksatsiya [Creeping and Relaxation]. Moscow: Visshaya shkola, 1976. 277 p. (rus)

32. Shteynberg V.V., Pletnev K.T., Grayzer V.M. Seysmostoykoye stroitelstvo. 1977. No. 1. Pp. 45-61. (rus)

Full text of this article in English: pp. 49-58

Mirsaidov M.M., Sultanov T.Z., Khodzhaev D.A. Stability evaluation of slopes of earth dams with account of soil rheological properties 